\title{
In vitro and in vivo analyses of a genetically-restricted antigen specific factor from mixed cell cultures of macrophage, $T$ and $B$ lymphocytes
}

\author{
CHAU RMW ${ }^{1}$ AND LAU ASK \\ Department Anatomy, University of Hong Konq, Hong Kong
}

\begin{abstract}
An immunostimulatory factor was identified 50 be secreted by antigen-pulsed macrophages. This factor was able to induce the generation of antigen specific $\mathrm{T}$ helper lymphocytes in vitro as well as in vivo. Further in vitro experiments testing for the genetic restriction of this factor indicated that it is a geneticallyrestricted antigen specific factor (ASF). The Cunningham plaque assay was used to quantify the generation of $\mathrm{T}$ helper lymphocytes by measuring the number of plaque forming cells after sequential incubations of antigen-pulsed macrophages with $\mathrm{T}$ lymphocytes, and then spleen cells, and finally the TNP-coated sheep red blood cells.
\end{abstract}

Key words: Antigen specific factor, genetic restriction, macrophages, lymphocytes, antigen presentation.

\section{INTRODUCTION}

It has been established that the classic antigen presenting cell is macrophage whose participation is required for the activation of many $\mathrm{T}$ lymphocyte functions. The importance of direct macrophage-lymphocyte contact in lymphocyte activation has been emphasized by several investigators[1, 2, 3, 4]. In the present study, we have examined the interactions between $\mathrm{T}$ cells and antigen-pulsed maorophages in order to test whether direct centact between the two cell types is an obligatory s step for the induction of antigen specific helper $\mathrm{T}$ cells in vitro, or additional mechanism also exists which is mediated by soluble immunostimulatory factors from maorophages.

We have also examined whether this induction of helper $\mathrm{T}$ cells $(\mathrm{T})$ by a putative macrophage factor, is genetically restricted as is the activation of specific immune T cells in the presence of antigen-bearing macrophages [5, 6, 7, 8]. Finally we have tested the genuine existence of ASF by the induction of helper T cells in vivo.

1 To whom correspondence should be addressed. 
Antigen specific factor from macrophages

\section{MATERIALS AND METHODS}

\section{Animals}

All mice were bred at the Laboratory Animal Unit, University of Hong Kong. The mouse strain used for the experiments was C57BL/6 unless specified otherwise. The mice were males aged between 9 to 12 weeks.

\section{Antigens}

The antigen used was horse spleen ferritin (HSF, Miles Laboratories) unless specified otherwise. Other antigens used were keyhole limpet hemocyanin (KLH, Sigma), horseradish peroxidase (HRP, Sigma) and bovine serum albumin (BSA, Sigma).

\section{Preparation of macrophages}

Mouse peritoneal macrophages were prepared according to the method of Beller and Unanue [9]. The peritoneal exudate cells were plated on either coverslips or culture flasks (Falcon), cultured for $2 \mathrm{hr}$ at $37^{\circ} \mathrm{C}$, and thereafter the nonadherent cells were removed by washing. Some preparations were treated with anti-Thy 1.2 (generous gift from N. I. H. , U. S. A.) and complement to remove any contaminating T cells which might absorb some of the factors produced by the maorophages.

\section{Preparation of T lymphocytes}

Mouse splenic T lymphocytes were isolated by nylon wool filtration based on the procedure described by Julius et al. [101. The viability of cells was greater than $95 \%$ as judged by dye exclusion ability. The proportion of surface membrane Ig + cells in this preparation was less than $3 \%$ as detected by staining with FITC-anti-mouse Ig. The percentage of Mac- $2^{+}$cells was less than $0.1 \%$ as detected by monoclonal antibody against routine maorophage surface Mac-2 antigen (from Boehringer Mannheim Biochemioals, U.S.A. . .

\section{Culture conditions}

Maorophages were pulsed with antigen $(20 \mu \mathrm{g} / \mathrm{ml})$ for $1 \mathrm{hr}$ after which the cells wore washed 4 times and then cultured either alone or together with $\mathrm{T}$ cells. To obtain a factor the antigen-pulsed maorophages were cultured in serum-free RPMI 1640 (Flow Laboratories) containing $2.2 \mathrm{~g} / \mathrm{l}$ of sodium bieabonate, $5 \mathrm{mM}$ HEPES (Research Organics), $2 \mathrm{~m} M$ L-glutamine (GIBCO), $100 \mathrm{units} / \mathrm{ml}$ Penicillin and $100 \mu \mathrm{g} / \mathrm{ml}$ Streptomycin (GIBCO). After 4 days, the culture supernatant which contained the factor was harvested and ultrafiltered with PM 10 membrane (Amieon Corporation) to remove dialysable substances. This crude supernatant was millipore-filtered before and after the PM 10 membrane ultrafiltration.

Lymphocytes were cultured in a similar medium with the additional oonstituents of $10 \%$ heat-inactivated fetal bovine serum (FBS, GIBC0) and $50 \mu \mathrm{M} 2$-mercaptoethanol (Sigma). 


\section{Binding of T cells to macrophage}

Normal and antigen-treated (obtained from mice each injected intraperitoneally with $100 \mu \mathrm{g}$ HSF in $10 \%$ peptone 3 days before sacrifice) macrophages wore co-cultured with $\mathrm{T}$ cells prepared from HSF-primed or unprimed mice for $3.5 \mathrm{hr}$ at $37^{\circ} \mathrm{C}$. The unbound $\mathrm{T}$ cells were then washed away gently. The monolayers of macrophages with the bound $\mathrm{T}$ cells were fixed, stained (Wright stain) and counted.

\section{Induction of helper $T$ cells and $T$-B cooperation}

Induction of antigen specific helper T cells was achieved by incubating nylon wool purified $\mathrm{T}$ cells with antigen-pulsed macrophages or the factor without any macrophags. After 4 days, a small number of viable cells $\left(5 \times 10^{4}\right)$ were washed and then added to cultures of spleen cells $\left(1 \times 10^{6}\right.$ cells per culture) which provided the B Jymphocytes. For each $\mathrm{T}$ cell sample, quadruplicate cooperabion culbures were set up. These cells were co-cultured in the presence of trinitrophenyl (TNP)-carrier $(0.1 \mu \mathrm{g} / \mathrm{ml})$ for 4 days after which the TNP specific plaque forming cells (PFC) were assayed with TNP-sheep red blood cells (TNP-SRBC) and complement.

\section{PFC assay}

The hemolytic PFG assay described by Cunningham and Szenberg [11] was adopted. The lymphocytes from the cooperation cultures were washed and mixed with TNP-SRBC and guinea pig serum which served as a source of comploment Rabbit anti-mouse IgG (Sigma) was included in some assays to test for the presence of, if any, IgG-producing B cells. The mixture was introduced into duplicate shallow chambers which were sealed with a molten mixture of paraffin wax and petroleum jelly (1:1) and incubated at $37^{\circ} \mathrm{C}$ for $3-4$ hour. The number of PFG per chamber was determined by scanning the entire chamber under the microscope, using the $10 \times$ objective.

\section{Induction of antigen-specific helper $T$ cells in rive}

Mice were injected intraperitoneally 3 times with either $0.5 \mathrm{ml}$ of saline or factor $(10$ $\mu \mathrm{g} / \mathrm{ml}$ ) per animal. No adjuvant was used in any of those injections. T cells were isolated from the spleens of these mice $1 \mathrm{wk}$ after the 3rd dose of injection and used for cooperation. Four days later, the PFG assay was done.

\section{Trinitrophenylation of proteins}

Soluble proteins were trinitrophenylated by the method of Rittenberg and Amkraut [12] using 2, 4, 6-trinitrobenzene sulfonic acid (Nutritional Biochemicals Corporation). The solution of coupled protein was dialysed and then passed through a column of Sephadox G25 (Pharmacia) to remove the side-reaction products. The coloured fraction in the void volume was collected and concentrated by PM 10 membrane ulrafiltration.

\section{Protein determination}

The amount of proteins in samples of the factor was determined by the method of Lowry et al. [13] using BSA as the standard. 
Antigen specific factor from macrophages

\section{RESULTS}

\section{Binding of T cells to macrophages.}

When mouse splenic $\mathrm{T}$ cells were added to peritoneal maorophages, some of these $\mathrm{T}$ cells became bound to the macrophages whether one or both cell types had previously encountered the antigen (HSF) or not. Tab. 1 shows that the antigen nonspecific binding between normal $\mathrm{T}$ cells and peritoneal maorophages was low with only $5 \%$ bound maorophages and wibh an average of $2.3 \mathrm{~T}$ cells per bound maorophage. Binding of HSF-primed T cells to normal maorophages was insignificantly higher than that of normal $\mathrm{T}$ cells. However, a significantly higher percentage $(10.5 \%)$ of bound macrophages with an average of $3 \mathrm{~T}$ cells per bound macrophage was observed when macrophages but not $\mathrm{T}$ cells had previously been treated with the antigen. These results indicate that encounter of antigen by macrophages prior to the binding experiment was more important than that by $\mathrm{T}$ cells for the physical interaction between macrophages and $\mathrm{T}$ cells. Best physical interaction was observed if both cell types had been exposed to the same antigen before the experiment.

Tab. 1 Einding of T cells to macrophages

\begin{tabular}{|c|c|c|c|}
\hline $\begin{array}{c}\text { Macrophages } \\
\left(5 \times 10^{5}\right)\end{array}$ & $\begin{array}{l}\text { T Cells } \\
\left(3 \times 10^{6}\right)\end{array}$ & $\begin{array}{l}\% \text { of bound } \\
\text { macrophages }\end{array}$ & $\begin{array}{l}\text { No. of } \mathrm{T} \text { cells }{ }^{\mathrm{f}} \\
\text { Bound } \mathrm{M} \phi\end{array}$ \\
\hline Control $^{\text {a) }}$ & Control $^{\mathrm{c})}$ & $5.0 \pm 0.8$ & $2.3 \pm 0.8$ \\
\hline Control $^{\text {a) }}$ & HSF-primed d) & $5.7 \pm 0.7$ & $2.6 \pm 0.6$ \\
\hline HSF-treated ${ }^{\mathrm{b})}$ & Control & $10.5 \pm 0.5$ & $3.0 \pm 0.2$ \\
\hline HSF-treated & HSF-primed & $14.3 \pm 0.7$ & $3.0 \pm 0.2$ \\
\hline
\end{tabular}
a) Peritoneal $\mathrm{M} \phi$ obtained from mice injected with $10 \%$ peptone.
b) As a) except injected with HSF ( $100 \mu \mathrm{g} / \mathrm{mouse})$ in $10 \%$ peptone.
c) $\mathrm{T}$ cells prepared from spleens of normal mice.
d) T cells prepared from spleens of HSF-primed mice.
e) The mean percentage of .T cell-bound $\mathrm{M} \phi$ per $200 \mathrm{M} \phi$ and the S. E. M. for 3 separate experiments $(\mathrm{n}=4)$.
f) The mean number of $T$ cells per bound $\mathrm{M} \phi$ in 20 bound $\mathrm{M} \phi$ and the S. E. M. $(\mathrm{n}=4)$.

\section{In vitro induction of helper $T$ cells}

Tab. 2 shows that only the antigen-pulsed macrophages were capable of inducing helper $\mathrm{T}$ cells in macrophage-T cell co-cultures. Macrophages pulsed with increased amounts of antigen were better antigen-presenting cells than those treated with lower amounts of antigen. Although the response is lower, helper $\mathrm{T}$ cells could also be generated when the antigen-pulsed macrophages and $\mathrm{T}$ cells were co-cultured without direct physical contact. This result suggests that direct macrophage-T cell contact was important but notobligatory for the induction of antigen specific helper $\mathrm{T}$ cells. Furthermore, it also indicates that certain immunosbimulatory factor produced by the antigen-pulsed macrophages was responsible for the induction of helper $\mathrm{T}$ cells in these cultures since antigen specific helper $\mathrm{T}$ cells were not obtained from cultures in which $\mathrm{T}$ cells were cultured alone or with unpulsed macrophages.

\section{Induction of helper T cells by macrophage-derived factor}

As shown in Tab. 3 supernatant harvested from cultures of antigen-pulsed maorophages 


\section{Chau RMW and Lau ASK}

Tab. 2 Generation of helper cells from interaction of antigen-pulsed macrophages and cells ${ }^{\mathrm{a})}$

\begin{tabular}{|c|c|c|c|c|c|}
\hline \multicolumn{2}{|c|}{$\begin{array}{l}\text { 1st Culture } \\
\mathrm{T}_{\mathrm{H}} \text { induction }\end{array}$} & \multicolumn{3}{|c|}{$\begin{array}{c}\text { 2nd Culture } \\
\text { T-B cooperation }\end{array}$} & \multirow{2}{*}{$\begin{array}{c}\begin{array}{c}\text { Anti-TNP } \\
\text { response }\end{array} \\
\text { PFC }^{\text {b) }}\end{array}$} \\
\hline $\begin{array}{l}\text { Macrophages } \\
\qquad\left(5 \times 10^{5}\right)\end{array}$ & $\begin{array}{l}\text { T cells } \\
\left(5 \times 10^{6}\right)\end{array}$ & $\begin{array}{c}\mathrm{T} / \mathrm{T}_{\mathrm{H}} \text { cells } \\
\text { transferred } \\
\left(5 \times 10^{4}\right)\end{array}$ & $\begin{array}{c}\text { Spleen } \\
\text { cells added } \\
(1 \times 10)^{6}\end{array}$ & $\begin{array}{l}\text { Challenge } \\
(0.1 \mu \mathrm{g} / \mathrm{ml})\end{array}$ & \\
\hline- & - & - & + & TNP-HSF & $60 \pm 12$ \\
\hline- & + & + & + & TNP-HSF & $30 \pm 10^{\mathrm{d})}$ \\
\hline unpulsed & + & + & + & TNP-HSF & $55 \pm 13$ \\
\hline HSF-pulsed $(10 \mu \mathrm{g} / \mathrm{ml})$ & + & + & + & TNP-HSF & $205 \pm 29^{\mathrm{e})}$ \\
\hline HSF-pulsed $(20 \mu \mathrm{g} / \mathrm{ml})$ & + & + & + & TNP-HSF & $275 \pm 25$ \\
\hline HSF-pulsed $(30 \mu \mathrm{g} / \mathrm{ml})$ & + & + & + & TNP-HSF & $305 \pm 62$ \\
\hline HSF-pulsed $(10 \mu \mathrm{g} / \mathrm{ml})^{\mathrm{C})}$ & + & + & + & TNP-HSF & $165 \pm 59^{f)}$ \\
\hline
\end{tabular}

a) $\mathrm{T}$ cells were co-cultured with macrophages which had either been pulsed or unpulsed with HSF. Four days later, the $\mathrm{T}$ cells were transferred to cultures of spleen cells. The generation of TH was measared by the cooperation between $\mathrm{T}$ and $\mathrm{B}$ cells in the presence of TNP-carrier and subsequently by the anti-TNP PFC assay.

b) The mean PFG number per culture and the S. E. M.

c) The maerophages which adhered to a coverslip were place on top of a grid after the $\mathrm{T}$ cells had settled onto the bottom of the culture vessel so that there was no direct contact between these two cell types.

d) Used as control for calculation of statistics by Student's t-test:

e) $\mathrm{p}<0.01$, f) $\mathrm{p}<0.01$.

Tab. 3 Induction of $\mathrm{T}_{\mathrm{H}}$ by $\mathrm{ASF}^{\mathrm{a})}$

\begin{tabular}{|c|c|c|c|c|c|}
\hline \multicolumn{2}{|c|}{$\begin{array}{l}\text { 1st Culture } \\
\mathrm{T}_{\mathrm{H}} \text { induction }\end{array}$} & \multicolumn{3}{|c|}{$\begin{array}{c}\text { 2nd Culture } \\
\text { T-B cooperation }\end{array}$} & \multirow{2}{*}{$\begin{array}{l}\text { Anti-TNP } \\
\text { response } \\
\mathrm{PFC}^{\mathrm{b})}\end{array}$} \\
\hline ASF & $\begin{array}{c}\mathrm{T} \text { cells } \\
\left(5 \times 10^{6}\right) \\
\end{array}$ & $\begin{array}{c}\mathrm{T} / \mathrm{T}_{\mathrm{H}} \text { cells } \\
\text { transferred } \\
\quad \underline{\left(5 \times 10^{4}\right)}\end{array}$ & $\begin{array}{c}\text { Spleen } \\
\text { cells added } \\
(1 \times 10)^{6} \\
\end{array}$ & $\begin{array}{l}\text { Challenge } \\
(0.1 \mu \mathrm{g} / \mathrm{ml}) \\
\end{array}$ & \\
\hline- & - & - & + & TNP-HSF & $63 \pm 19$ \\
\hline- & + & + & + & TNP-HSF & $40 \pm 14^{\mathrm{d})}$ \\
\hline $\mathrm{ASF}_{\mathrm{KLH}}{ }^{\mathrm{C})}$ & + & + & + & TNP-HSF & $355 \pm 39^{\mathrm{e})}$ \\
\hline $\mathrm{ASF}_{\mathrm{KLH}}$ & + & + & + & TNP-HSF & $15 \pm 5$ \\
\hline- & + & + & + & TNP-HSF & $15 \pm 5$ \\
\hline- & + & + & + & TNP-HSF & $15 \pm 5$ \\
\hline $\mathrm{ASF}_{\mathrm{HSF}}$ & + & + & + & TNP-HSF & $15 \pm 5$ \\
\hline $\mathrm{ASF}_{\mathrm{HSF}}$ & + & + & + & TNP-HSF & $15 \pm 5$ \\
\hline $\mathrm{ASF}_{\mathrm{KLH}}$ & + & + & + & TNP-HSF & $15 \pm 5$ \\
\hline $\mathrm{ASF}_{\mathrm{KLH}}$ & + & + & + & TNP-HSF & $15 \pm 5$ \\
\hline $\mathrm{ASF}_{\mathrm{KLH}}$ & + & + & + & TNP-HSF & $15 \pm 5$ \\
\hline $\mathrm{ASF}_{\mathrm{KLH}}$ & + & + & + & TNP-HSF & $15 \pm 5$ \\
\hline $\mathrm{ASF}_{\mathrm{KLH}}$ & + & + & + & TNP-HSF & $15 \pm 5$ \\
\hline
\end{tabular}

a) ASF harvested item antigen-pulsed macrophage cultures was introduced into T cell cultures. The generation of TH was measured as described in footnote a) of Table 2.

b) The mean PF0 number per culture and the S. E. $\sim$ f.

c) ASF from macrophages pulsed with KLH.

d) Used as controls for calculation of statistics by Student's t-lest:

e) p $<0.01$, f) $\mathrm{p}<0.01$, g) $\mathrm{p}<0.01$. 
Antigen specific factor from macrophages

was capable of inducing helper $\mathrm{T}$ cells in the absence of macrophages or any additional

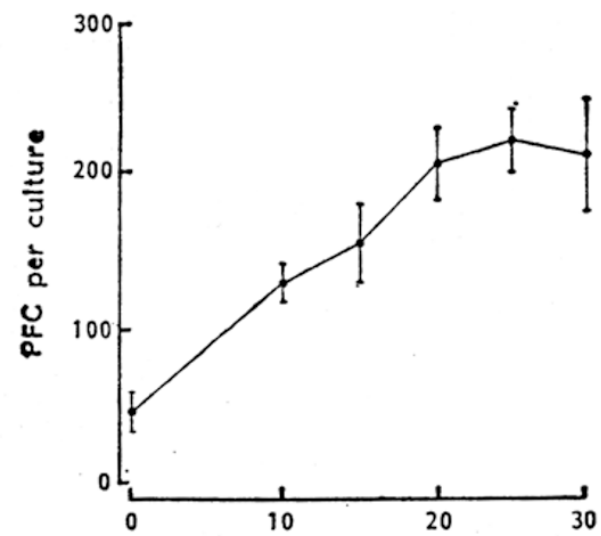

Amount of crude ASF in $T_{H}$ induction ( $\mu \mathrm{g}$ of proteinș)

Fig. 1 Effect of graded amounts of ASF on helper cel] induction. Various amounts of crude ASF were added to cultures of $\mathrm{T}$ cells. The generation of $\mathrm{TH}$ was measured as described in footnote a) of Table 2.Each result represents the mean + S.E.M. of quadruplicate cu]tures. antigen. These helper $\mathrm{T}$ cells were antigen specific because the T-B cooperation cultures yielded high number of PFC only if challenged with TNP conjugated So She antigen used for obtaining the factor. Similar results were obtained for all three soluble antigens studied. We named this macrophage-derived immunostimulatory moiety antigen-specific factor or ASF.

Fig. 1 represents the dose response curve of ASF to determine the optimal concentration for induetion of helper $\mathrm{T}$ cells. The graph shows that this optimum was about 20-30 $\mu \mathrm{g}$ of crude ASF (PM 10 membrane ultrafilltered macrophage culture supernatant). The difference between $0 \mu \mathrm{g}$ and $10 \mu \mathrm{g}$ of crude ASF and that bebween $10 \mu \mathrm{g}$ and $20 \mu \mathrm{g}$ were significant, $\mathrm{p}<0.01$ and $\mathrm{p}<0.05$ respectively.

\section{Speciticity of antibody forming cells generated from T-B cooperation}

In order to demonstrate that the antibody forming cells generated from T-B cooperation were TNP specific, TNP-BSA or normal SRBC were used in some assay chambers. Tab. 4 shows that the excess TNP-BSA present in the assay completely inhibited plaque formabion probably by competition for TNP specific antibodies with the TNP-SRBC. A second teat for TNP specificity was used to make sure that the excess TNP-BSA did not inhibit plaque formation by interfering with the functions of antibody-forming cells. The use of normal SRBC instead of TNP-SRBC in the assay yielded negligible number of PFC. This excludes the possibility that these cells produced cytotoxic substances which were responsible for

Tab. 4 Specificity of an $\sim$ iboay forming cells generaf $\sim$ l from T-B ccopera $\sim$ ion

\begin{tabular}{lc}
\hline \multicolumn{1}{c}{ Assay conditions } & PFC+S. E. M. \\
\cline { 2 - 2 } Control $^{\text {a) }}$ & $25 \pm 8^{\mathrm{f})}$ \\
Normal $^{\text {b) }}$ & $150 \pm 14^{\mathrm{g})}$ \\
Normal-I-TNP-BSA added to PFG assay $^{\mathrm{c})}$ & $17 \pm 8$ \\
Normal except SRBC unhaptenated $^{\text {() }}$ & $4 \pm 4$ \\
Normal $^{+ \text {Rb anti-MlgG added to PFC assay }}{ }^{\mathrm{e})}$ & $183 \pm 40^{\mathrm{h})}$ \\
\hline
\end{tabular}
a) No T cells transferred from first culture into second culture.
b) The generation of $\mathrm{T}_{\mathrm{H}}$ was measured in the usual manner (see footnote a) of Table 2).
c) TNP-SRI C were mixed with competing TNP-BSA $(0.11 \mathrm{mg} / \mathrm{chamber})$ before used for PFC assay.
d) SRBC used in PFC assay were unhaptenated.
e) Rabbit avti-mouse IgG developing serum ( $4 \mu \mathrm{l} /$ chamber $)$ was included in the assay mixture.
f) Used as control for calculation of statistics by Student's t-test.
g) $\mathrm{p}<0.01$.
h) Not significant compared with normal assay condition. 
plaque formation. The requirement for haptenated SRBC in the formation of hemolytic plaques implies that the antibodies produced were happen specific.

The addition of rabbit anti-mouse IgG developing serum to the assay mixtmre did not yield more hemolytic plaques than the direct plaque assay. This indicates that only IgM and no IgG antibody-forming cells were found in our cultures in which unprimed B cells were employed.

\section{Inability of ASF from allogeneic macrophages to facilitate inductioiz of helper T cells}

If the strain of mice used for the preparation of $\mathrm{T}$ cells was different from that used for obtaining ASF, then only control levels of PF0 were obtained as illustrated in Tab. 5 The requirement for syngeneic macrophages and $\mathrm{T}$ cells suggests that helper $\mathrm{T}$ cell induction by ASP is likely yo be genetically restricted.

Tab. 5 Inability of ASF from allogeneic macrophages to $\mathrm{t} \sim$ acilitate TH induction

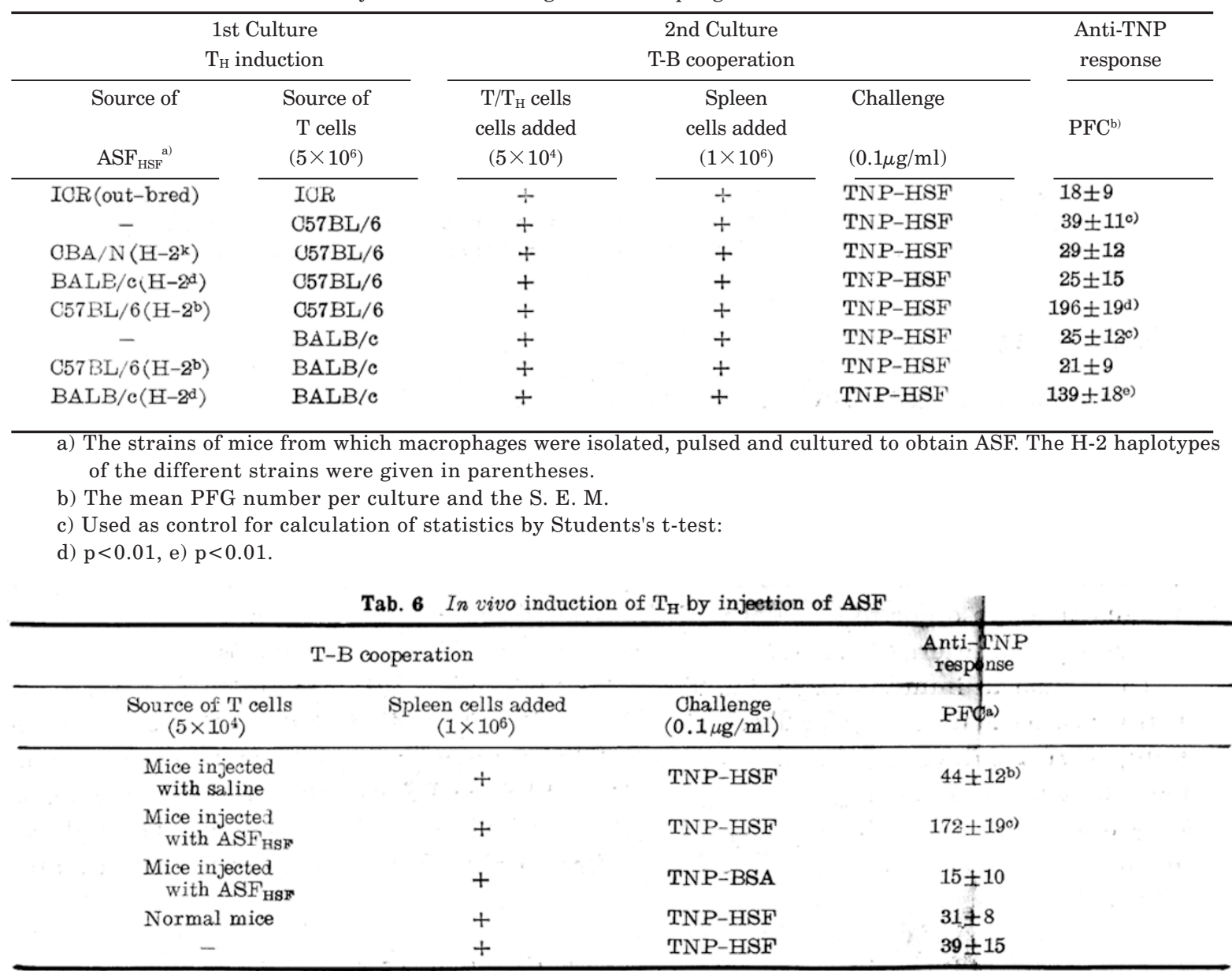

a) The mean PFG number per culture and the S. E. M.

b) Used as control for calculation of statistics by Students's t-test:

c) $\mathrm{p}<0.01$. 
Antigen specific factor from macrophages

\section{In vice induction of helper $T$ cells}

So far, activity of ASF appears to be one of the mechanisms of $\mathrm{T}$ cell activation in vitro. However, these studies on ASF would bear much more significance if ASF can be shown to be active in vivo as well. Tab. 6 shows that $\mathrm{T}$ cells isolated from mice injected with ASF indeed contained antigen specific helper T cells. In addition, increased number of such T cells introduced into T-B cooperation cultures resulted in greater number of PFC (Fig. 2).

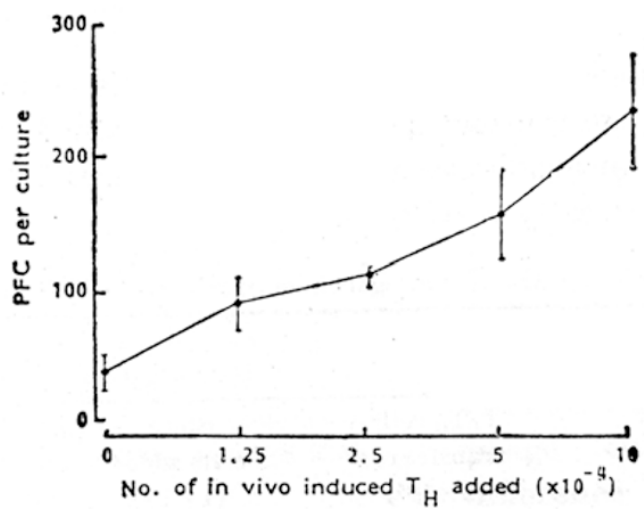

Fig. 2 Effect of graded numbers of in vivo induced TH on geneation of PFC in T-B cooperation. Various numbers of in vivo induced TH were used in T-B cooperation cultures. Four days later, the PFC assay was performed. Each result represents the mean' S. E. M. for quadruplicate cultures.

\section{DISCUSSION}

In the macrophage-T binding experiments, delayed fixation and scoring $(\mathrm{t}=5-24 \mathrm{hr}$ ) yielded decreasing number of lymphocytes bound to macrophages (data not shown). This was probably due to dissociation of lymphocytes from the macrophages caused primarily by the decay of antigen-induced changes in macrophages as reported by Ben-Sasson et al. [14]. This dissociation should be important in an immune response in vivo. After interaction with macrophages, it is desirable for the $\mathrm{T}$ cells to migrate to other sites within the lymphoid tissue in order to interact with $\mathrm{B}$ cells and other $\mathrm{T}$ cell subsets.

The physical interaction between macrophages and $\mathrm{T}$ cells represents an example of cell cooperation in immune responses. There is considerable evidence which suggests that this interaction is necessary for $\mathrm{T}$ cell stimulation $[15,2,3,4]$ but definitive evidence is lacking. Our results show that direct physical interaction between these two cell types is important but not obligatory for the generation of helper $\mathrm{T}$ cells. The results in Tab. 3 clearly indicate that ASF harvested from antigen-pulsed macrophage cultures is capable of inducing antigen specific helper $\mathrm{T}$ cells in vitro in the absence of macrophages or any additional antigen.

The importance of direct macrophage-lymphocyte contact in antigen presentation and the involvement of soluble immunostimulatory factors like ASF are not as contradictory as they may first appear. The two modes of antigen presentation are not mutually exclusive. The action of soluble immunostimulatory factors may be augmented by the development of 
physical contact between macrophages and T cells. Furthermore, macrophage-lymphocyte clusters may provide a focus for and thus enhance T-B cooperation [16].

There are results reported by several other groups which are analogous to ours $[17,18$, 19]. These provide strong support for the genuine existence and importance of immunostimulatory factors like ASF. These ASF-like factors were given different names by different investigators: genetically related factor (GRF) [17], In-positive moiety (IPM) [18] and In-containing antigen complex (IAC) [19]. Apparently, it will be worthy to test whether all these immunostimulatory factors are in fact the same factor.

We have attempted to purify ASF and characterize it. Preliminary findings showed that ASF is a complex of processed antigen fragment and an I-region-defined antigen (In) moiety (unpublished results). This is consistent with the reports that presentation of antigen is in the context of an Ia complex [17, 18, 19, 20,21].

Our observation that induction of helper T cells by ASF appears to be genetically restricted is also consistent with the findings reported by various groups $[17,18,19,7,8]$. Because of the difficulty in the availability of different inbred mouse strains in Hong Kong, we were unable to map the histocompatibility requirement for macrophage-T or ASF-T interaction to any particular region of the major histocompatibilify complex.

Although the antigen-presenting role played by macrophages in the generation of $\mathrm{T}$ cell immune responses has boon established, neither the pathway of antigen through the cell nor the precise biochemical events in antigen processing have been elucidated. At present, we are attempting to follow the intracellular fate of an antigen subsequent to endocytosis by macrophages. HSF was chosen to be the antigen because its electron dense property enables us to identify it easily in an electron micrograph. Even if this antigen processing pathway can be worked out, the question whether intracellular antigen processing by antigen-presenting cell is obligatory for presentation of antigen has yet to be solved; because nonphagocytic dendritic cells which hardly process any antigen have been. reported to be very potent antigen presenting cells [22, 23, 24]. Furthermore, extracellular (cell-flee) antigen processing has been observed [25].

\section{REFERENCES}

[ 1 ] RS Geha, ME Jonson, BH Ault, E Yunis and MD Broff. Macrophage T cell interaction in man: Binding of antigen-specific human proliferating and helper T cells to antigen-pulsed macrophages. J Immune1 1981; 126: 781-786.

[ 2 ] PE Lipsky and AS Rosenthal. Macrophage-lymphocyte interaction II. Antigen-mediated physical interactions between immune guinea pig lymph node lymphocytes and syngeneic macrophages. 1975; 141: 138-154.

[ 3 ] O Werdelin, D Braendstrup and EM Shevach. Specific absorption of T lymphoctyes by incubation on antigenpulsed macrophage monolayers. J Immune1 1979; 123: 1755-1762.

[ 4 ] K Ziegler and ER Unanue. The specific of Listeria monocytogenes-immune T lymphocytes to macrophages I. Quantitation and role of H-2 gene products. J Exp Me,t 1979; 150: 1143--1160.

[ 5 ] O Braendstrup, O Werdelin, EM Shevach and AS Rosenthal. Macrophage-lymphocyte clusters in the immune response to soluble protein antigen in vitro VII. Genetically restricted and nonrestricted physical interactions. J Immunol 1979; 122: 1608--1613.

[ 6 ] T Taniyama and HT Holden. Requirement off histocompatible macrophages for the induction of a secondary cytotoxic response to syngenetic tumor cells in vitro. J Imrnunol :1979; 123: 43-49.

[ 7 ] P Vogt, P Erb, B Keller and M Feldmaun. Nature of macrophage-T cell interaction in secondary helper cell generation in vitro Genetic restriction of macrophage-T cell interaction, which determines T-B genetic restriction. Eur J Immunol 1981; 11: 377-381.

[8] A Yano and RH Schwartz and WE Paul. Antigen presentation in the murine T-lymphocyte proliferative response I.Requirement for genetic identity at major histocompatibility complex. J Exp Med 1977;146: 


\title{
Antigen specific factor from maerophages
}

\author{
$828-843$.
}

[ 9 ] DI Beller and ER Unanue. Regulation of macrophage populations II. Synthesis and expression of Ia antigens by peritioneal exudate macrophages is a transient event. J Immunol 1981; 126: 263—269.

[10] MH Julius, E Simpson and LA Herzenberg. A rapid method for the isolation of functional thymus-derived routine lymphocytes. Eur J Immunol 1973; 3: 645-653.

[11] AJ Cunningham and A Szenberg. Further improvements in the plaque for detecting signal antibody-forming cells. Immunology 1968; 14: 599-601.

[12] MR Rittenberg and AA Amkraut. Immunogeneticity of trintrophenyl-hemocytanin: produuction of primary and seondary anti-hapten precipitins. J Immunol 1966; 97: 421-430.

[13] OH Lowry, NJ Rosebrough, AL Farr and RJ Randall. Protein measurement with the folin phenol reagent. J Biol Chem 1951; 193: 265-275.

[14] SZ Ben-Sasson, MF Lipscomb, TF Tucker and JW Uhr. Specific binding of T lymphocytes to macrophages III. Spontaneous dissociation of T cells from antigen-pulsed macrophages. J Immunol 1978; 120: 1902 -1906.

[I5] SZ Ben-Sasson, NIF Lipscomb, TF Tucker and JW Uhr, Specific biding of T lymphocytes to macrophages II, Role of macrophage-associated antigen. J Immunol 1977; 119: 1493-1500.

[16] DH Katz and ER Unanue. Critical role of determinant presentation in the induction of specific responses in immunocompetent ]ymphecytes. J Exp Med 1973; 137: 967-990.

[17] M Feldmann, P Erb, S Kontiainen, I Todd and JN Woody. Comparison of antigen-specific I-region-associated cell interaction factors. Ann N Y Acad Sci 1979; 332:591-604.

[18] A Friedman, R Zerubavel, C Gitler and IR Cohen. Molecular events in the processing of avidin by antienpresenting cells $(\mathrm{AP}(\mathrm{J})$. III: Activation of T-lymphocyte lines and H-2 restriction are mediated by processed aviding associated with I-region gene prolucts. Immunogenetics 1983; 18: 291-302.

[19] J Puri and P Lonai. Mechanism of antigen binding by T cells H-2(I-A)-restricted binding of antigen plus Ia by helper cells. J Immunol 1978; 10: 273-281.

[20] RH Schwartz, A Yano and WE Paul. Interaction between antigen presenting cells and primed T lymphocytes: An assessment of Ir gene expression in the antigen-presenting cell. Immunol Rev 1978; 40: 153--180.

[21] ER Unanue, DI Beller, CY Lu and PM Allen. Antigen presentation: Comments on its regu]taion and mechanism. J Immunol 1984; 132: 1--5.

[22] JE Niederhuber and P Allen. Role of I-region gene products in macrophage induction of an antibody response II. Restriction at the level of $\mathrm{T}$ cell in recognition of I-J-subregion macrophsge determinants. J Exp Med 1980; 151: 1103-] 113.

[23] K Inaba, RM Steinman, WC Van Voorhis and S Muramatsu. Dendritic cells are critical accessory cells for thymus-dependent antibody responses in mouse and in man. Proc. Natl Acad Sci USA 1983 80: $6041--6045$.

[24] WEF Klinkert, JH LaBadie and WE Bower. Accessory and stimulating properties of dendritic cells and macrophages isolated from varius rat tissues. J Exp Med 1982; 156: 1-9.

[25] R Shimonokevitz, J Kappler, P Marrack and HM Grey. Antigen recognition by H-2-restricted T cells 1. (Jellfree antigen processing. J Exp Med 1983; 158: 303-316.

\section{Received 17-3-1990. Revised 8-5-1990. Accepted 13-6-1990.}

